\title{
Vagrancy in paradise: documentation of the chevron butterflyfish Chaetodon trifascialis in Kaneohe Bay, Oahu, Hawaiian islands
}

\author{
Erik C. Franklin
}

\begin{abstract}
The chevron butterflyfish Chaetodon trifascialis is an obligate corallivore found on Indo-Pacific coral reefs. The typical northern extent of the distributional range of the chevron butterflyfish overlaps with the occurrence of one of its preferred corals Acropora cytherea on reefs of French Frigate Shoals in the Northwestern Hawaiian Islands. Here I document the occurrence of a single C. trifascialis in Kaneohe Bay, Oahu outside its typical range and discuss the role of biogeographic vagrants as potential colonizers that provide direct evidence of inter-island larval connectivity in the Central Pacific Ocean.
\end{abstract}

Keywords: Chaetodon trifascialis, Butterflyfish, Coral reef, Oahu, Vagrant species, Biogeography, Hawaiian islands

\section{Background}

The chevron butterflyfish Chaetodon trifascialis Quoy \& Gaimard, 1825 is an obligate corallivore found on IndoPacific coral reefs. The species exhibits a strong ecological relationship with corals of the genus Acropora, in particular A. hyacinthus, and A. cytherea (Berumen \& Pratchett, 2008; Berumen et al., 2012; Lawton et al., 2012; Pratchett et al., 2013; Pratchett et al., 2006). Typically, harems of $C$. trifascialis occupy a home range and feed primarily on Acropora corals (Yabuta \& Berumen, 2013). Due to the specialist diet on corals, $C$. trifascialis has been suggested as an indicator species for the condition of coral reefs (Reese, 1981; Ohman et al., 1998). Globally, C. trifascialis is in "near threatened" status by the IUCN due to the susceptibility of corals to bleaching events (Carpenter \& Pratchett, 2010). For example, the C. trifascialis was not observed from reefs that experienced massive bleaching events in follow-up surveys at sites where they had been previously documented (Pratchett et al., 2006). While C. trifascialis is distributed throughout the IndoPacific, it only occurs commonly in one location of the Hawaiian archipelago, French Frigate Shoals, where Acropora cytherea is well established (Asher et al., 2012; Randall, 2007; Grigg, 1981).

Correspondence: erik.franklin@hawaii.edu

Hawaii Institute of Marine Biology, School of Ocean and Earth Science and Technology, University of Hawaii at Manoa, Kaneohe, HI, USA
This study documents the occurrence of a single $C$. trifascialis in Kaneohe Bay, Oahu, Hawaiian Islands and discusses the role of biogeographic vagrants in this region as potential colonizers that demonstrate interisland larval connectivity.

\section{Methods}

One specimen of C. trifascialis was observed and photographed during a dive on September 4, 2013 in a coral patch reef at $21^{\circ} 27^{\prime} 5.04^{\prime \prime} \mathrm{N}$ and $157^{\circ} 47^{\prime} 25.537^{\prime \prime} \mathrm{W}$ in Kaneohe Bay, Oahu, Hawaiian Islands (Fig. 1). The specimen was not collected because the author did not possess a Hawaii state collection permit for that particular species at the time of observation. The site was characterized by a stand of Pocillopora meandrina corals in the back reef of Kaneohe Bay near Sampan Channel.

\section{Results}

One specimen of C. trifascialis was observed and photographed within the branches of a Pocillopora meandrina coral colony at $4 \mathrm{~m}$ depth (Fig. 2). The fish was visually estimated as $5 \mathrm{~cm}$ TL and not collected. The coral colony was located in back reef habitat with isolated coral patches among surrounding extents of sand-bottom in Kaneohe Bay. No additional specimens of C. trifascialis were encountered during four dives (total time $2 \mathrm{~h}$ ) in the general vicinity of the initial observation. 


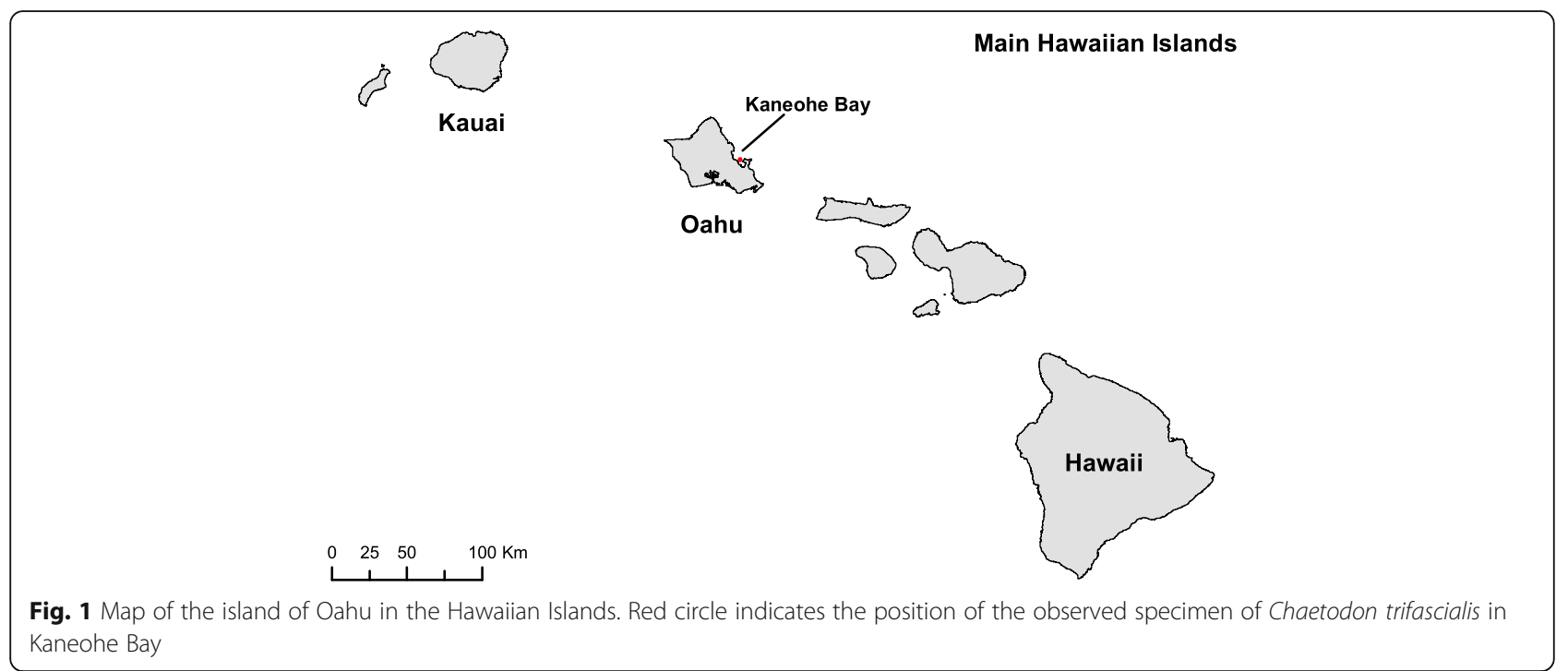

\section{Discussion}

The northern range of Chaetodon trifascialis has been observed on reefs of French Frigate Shoals in the Northwestern Hawaiian Islands, yet documented evidence of specimens has not been recorded elsewhere in the Hawaiian archipelago. For example, a regional-scale reef fish monitoring survey program of the Hawaiian Islands by NOAA from 2000 to 2016 did not observe a single specimen of C. trifascialis in the MHI (I. Williams pers. comm.). Prior anecdotes of C. trifascialis on Oahu reefs were described by Reese (Reese, 1981) but not supported with primary evidence, so this record represents the first documented observation of the species in the main

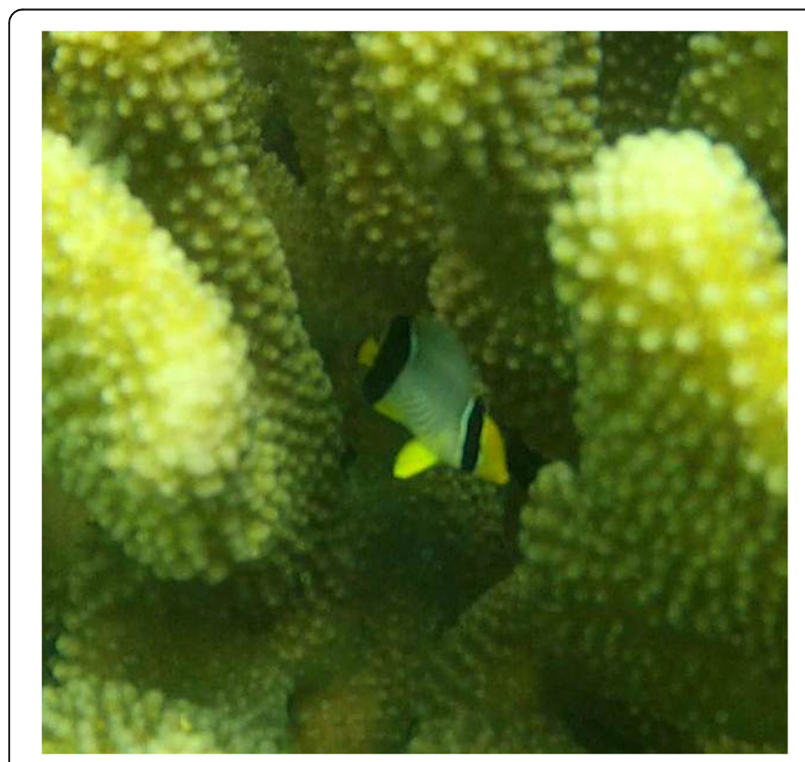

Fig. 2 Photograph of a specimen of Chaetodon trifascialis observed within the branches of Pocillopora meandrina in Kaneohe Bay, Oahu, HI
Hawaiian Islands. Other observations of C. trifascialis on Oahu reefs were made in Kaneohe Bay in 1983 (R. Kosaki pers. comm.) and Hanauma Bay in the late 1980's or early 1990's (B. Mundy pers. comm.). Given known larval connectivity pathways, the specimen of $C$. trifascialis was most likely a vagrant species from Johnston Atoll (Kobayashi, 2006; Wren et al., 2016).

Vagrant butterflyfish species are not uncommon. A review of geographical distribution shifts in 52 fish families found that butterflyfish (family: Chaetodontidae) had a significantly higher proportion of vagrants than expected by species richness given each family's total number of species (Feary \& Pratchett, 2014). For example, in the Azores and Madeira Islands off the western African coast, only vagrant butterflyfish species have been observed and there are no known permanent populations (Kulbicki et al., 2013). The vagrant species observed in the Azores, Chaetodon sedentarius, is commonly distributed in the western Atlantic and Caribbean region (Allen et al., 2010). Two butterflyfishes, C. lunula (Pyle et al., 2010) and C. unimaculatus (Myers \& Pratchett, 2010a), are Indo-Pacfic species that are biogeographic vagrants in the Galapagos Islands. Furthermore, a single individual of the black butterflyfish $C$. flavirostris has been observed as a vagrant species at Easter Island (Myers \& Pratchett, 2010b). These examples are not comprehensive but provide a sample to demonstrate the relative commonness of butterflyfish vagrant species.

In the Hawaiian archipelago, larval connectivity from Johnston Atoll represents the most likely source for periodic colonization of reef fauna, such as butterflyfish (family: Chaetodontidae) and stony corals of family Acroporidae (Kobayashi, 2006; Wren et al., 2016). The overlap in butterflyfish species composition between the Hawaiian archipelago and Johnston Atoll is nearly 
complete, with the exception of $C$. fremblii which has not been observed at Johnston Atoll (Randall, 2007; Kosaki et al., 1991; Randall et al., 1985; Wagner et al., 2014). The lined butterflyfish $C$. lineolatus has been rarely observed at Johnston Atoll (Randall et al., 1985), so could be described as a biogeographic vagrant there. The Acropora corals that are the primary prey for $C$. trifascialis are commonly found at French Frigate Shoals in the Northwestern Hawaiian Islands but have been very rarely sighted in the main Hawaiian Islands (Asher et al., 2012; Grigg et al., 1981). Isolated Acropora cytherea colonies have been recorded off the islands of Kauai (Grigg et al., 1981; Maragos, 1977; Kenyon et al., 2007) and Oahu (Kosaki et al., 2013) but attempted resightings for these colonies have failed. While most singleton species arrivals to the Hawaiian Islands probably perish, several large colonies of Acropora gemmifera were observed in April 2013 on the Kona coast of Hawaii Island (Walsh et al., 2013). The size of the A. gemmifera corals suggested that they had been present for decades in the area. Grigg (Grigg, 1981) hypothesized that Acropora were in the process of post-Pleistocene recolonization from larval dispersal outside of the archipelago. Given the obligate feeding relationship of $C$. trifascialis on Acropora corals, a successful colonization of C. trifascialis would require the pre-establishment of Acropora to settlement sites in the main Hawaiian Islands. The probability of this occurrence is low but not impossible especially if range expansions of these Acropora species to the MHI are facilitated by the predicted increases of sea surface temperatures under changing climates (Baird et al., 2012; Yamano et al., 2011). Under future warming conditions with enough larval supply and survival, the successful colonization and establishment of both Acropora species and C. trifascialis from Johnston Atoll to sites in the Main Hawaiian Islands may be possible as a continued recolonization of the Hawaiian archipelgo (Grigg, 1981; Kobayashi, 2006; Maragos \& Jokiel, 1986).

\section{Acknowledgements \\ I thank J. Randall for confirmation of the species identification, R. Kosaki, B. Mundy, I. Williams, P. Ayotte, A. Gray, J. Asher, and K. Lino for sharing survey information about Chaetodontidae of the Hawaiian Islands and Johnston Atoll, and two anonymous reviewers for improving this manuscript. This is HIMB contribution \#1701 and SOEST contribution \#10110.}

\section{Funding}

NOAA award \#NA10NMF4520163.

\section{Availability of data and materials}

All data generated or analyzed during this study are included in this published article.

\section{Author's contributions}

EF conceived and performed the experiment, analyzed the data, and wrote the manuscript.

Ethics approval and consent to participate Not applicable.
Consent for publication

Not applicable.

\section{Competing interests}

The author declares that he has no competing interests.

\section{Publisher's Note}

Springer Nature remains neutral with regard to jurisdictional claims in published maps and institutional affiliations.

Received: 13 April 2017 Accepted: 14 August 2017

Published online: 21 August 2017

\section{References}

Allen GR, Floeter S, McEachran JD: Chaetodon sedentarius. The IUCN Red LIst of Threatened Species 2010, 2010:e.T155220A4749409.

Asher J, Maragos J, Kenyon J, Vargas-Angel B, Coccagna E. Range extensions for several species of Acropora in the Hawaiian archipelago and Papahanaumokuakea marine National Monument. Bull Mar Sci. 2012;88:337-8.

Baird AH, Sommer B, Madin JS. Pole-ward range expansion of Acropora spp along the east coast of Australia. Coral Reefs. 2012;31:1063.

Berumen ML, Pratchett MS. Trade-offs associated with dietary specialization in corallivorous butterflyfishes (Chaetodontidae: Chaetodon). Behav Ecol Sociobiol. 2008:62:989-94.

Berumen ML, Trip EDL, Pratchett MS, Choat JH. Differences in demographic traits of four butterflyfish species between two reefs of the great barrier reef separated by 1,200 km. Coral Reefs. 2012;31:169-77.

Carpenter KE, Pratchett M: Chaetodon trifascialis. The IUCN Red List of Threatened Species 2010, 2010:e.T165712A6098323.

Feary DA, Pratchett MS. J Emslie M, fowler AM, Figueira WF, Luiz OJ, Nakamura Y, booth DJ: latitudinal shifts in coral reef fishes: why some species do and others do not shift. Fish Fish. 2014;15:593-615.

Grigg RW. Acropora in Hawaii .2. Zoogeography. Pac Sci. 1981;35:15-24.

Grigg RW, Wells JW, Wallace C. Acropora in Hawaii .1. History of the scientific record, Systematics, and ecology. Pac Sci. 1981;35:1-13.

Kenyon J, Godwin S, Montgomery A, Brainard R. Rare sighting of Acropora Cytherea in the main Hawaiian islands. Coral Reefs. 2007:26:309.

Kobayashi DR. Colonization of the Hawaiian archipelago via Johnston atoll: a characterization of oceanographic transport corridors for pelagic larvae using computer simulation. Coral Reefs. 2006:25:407-17.

Kosaki RK, Pyle RL, Randall JE, Irons DK. New records of fishes from Johnston atoll, with notes on biogeography. Pac Sci. 1991;45:186-203.

Kosaki RK, Wagner D, Leonard JC, Hauk BB, Gleason KA. First report of the table coral $<\mid>$ Acropora Cytherea $</ \mid>$ (Scleractinia: Acroporidae) from Oahu (main Hawaiian islands). Bull Mar Sci. 2013;89:745-6.

Kulbicki M, Vigliola L, Wantiez L, Hubert N, Floeter SR, Myers RF. Biogeography of butterflyfishes: a global model for reef fishes? In: Prachett MS, Berumen ML, Kapoor BG, editors. Biology of Butterflyfishes. Boca Raton, FL: CRC Press; 2013.

Lawton RJ, Cole AJ, Berumen ML, Pratchett MS. Geographic variation in resource use by specialist versus generalist butterflyfishes. Ecography. 2012;35:566-76.

Maragos J. Order Scleractinia. In: EL DDW, editor. Reef and shore fauna of Hawaii section 1: protozoa through Ctenophora. Honolulu: Bishop Museum; 1977. p. 158-241.

Maragos JE, Jokiel PL. Reef corals of Johnston atoll: one of the world's most isolated reefs. Coral Reefs. 1986;4:141-50.

Myers R, Pratchett M: Chaetodon unimaculatus. The IUCN Red List of Threatened Species 2010, 2010a:e.T165714A6099340.

Myers R, Pratchett M: Chaetodon flavirostris. The IUCN Red List of Threatened Species 2010, 2010b:e.T165688A6091974.

Ohman MC, Rajasuriya A, Svensson S. The use of butterflyfishes (Chaetodontidae) as bio-indicators of habitat structure and human disturbance. Ambio. 1998; 27:708-16.

Pratchett MS, Graham NA, Cole AJ. Specialist corallivores dominate butterflyfish assemblages in coral-dominated reef habitats. J Fish Biol. 2013;82:1177-91.

Pratchett MS, Wilson SK, Baird AH. Declines in the abundance of Chaetodon butterflyfishes following extensive coral depletion. J Fish Biol. 2006;69: 1269-80.

Pyle R, Craig MT, Pratchett M: Chaetodon Iunula. The IUCN Red List of Threatened Species 2010, 2010:e.T165651A6080984.en.

Randall JE. Reef and shore fishes of the Hawaiian islands. Honolulu: Sea Grant College Program, University of Hawai'i; 2007. 
Randall JE, Lobel PS, Chave EH. Annoted checklist of the fishes of Johnston Island. Pac Sci. 1985;39:24-80.

Reese ES. Predation on corals by fishes of the family Chaetodontidae:

implications for conservation and management of coral reef ecosystems. Bull Mar Sci. 1981;31:594-604.

Wagner D, Kosaki RK, Spalding HL, Whitton RK, Pyle RL, Sherwood AR, Tsuda RT, Calcinai B. Mesophotic surveys of the flora and fauna at Johnston atoll, Central Pacific Ocean. Marine Biodiversity Records. 2014;7:e68.

Walsh WJ, Cotton S, Jackson L, Lamson M, Martin R, Osada-D'Avella K, Preskitt L. First record of Acropora Gemmifera in the main Hawaiian islands. Coral Reefs. 2013;33:57.

Wren JL, Kobayashi DR, Jia Y, Toonen RJ. Modeled population connectivity across the Hawaiian archipelago. PLoS One. 2016;11:e0167626.

Yabuta S, Berumen ML. Social systems and spawning behavior of Chaetodon butterflyfish. In: Pratchett MS, Berumen ML, Kapoor BG, editors. Biology of Butterflyfishes. Boca Raton, FL: CRC Press; 2013.

Yamano H, Sugihara K, Nomura K. Rapid poleward range expansion of tropical reef corals in response to rising sea surface temperatures. Geophys Res Lett. 2011;38:L04601.

Submit your next manuscript to BioMed Central and we will help you at every step:

- We accept pre-submission inquiries

- Our selector tool helps you to find the most relevant journal

- We provide round the clock customer support

- Convenient online submission

- Thorough peer review

- Inclusion in PubMed and all major indexing services

- Maximum visibility for your research

Submit your manuscript at www.biomedcentral.com/submit
Biomed Central 